\title{
Strategi Orang tua Mengatasi Kejenuhan Anak Belajar dari Rumah Selama Pandemi Covid-19
}

\author{
Ade Agusriani $^{1 凶}$, Mohammad Fauziddin ${ }^{2}$ \\ Pendidikan Islam Anak Usia Dini, Universitas Islam Negeri Alauddin Makassar(1) \\ Pendidikan Guru Pendidikan Anak Usia Dini, Universitas Pahlawan Tuanku Tambusai(2) \\ DOI: $\underline{10.31004 / \text { obsesi.v5i2.961 }}$
}

\begin{abstract}
Abstrak
Penelitian ini dilakukan untuk mengetahui strategi orang tua mengatasi kejenuhan anak belajar dari rumah selama masa pandemic covid-19. Penelitian ini menggunakan metode penelitian survei deskriptif. Pengambilan sampel menggunakan teknik purposive sampling dengan kriteria orang tua domisili kota Makassar yang memiliki anak yang berusia 4 hingga 6 tahun. Sampel pada penelitian ini sebanyak 105 responden yang dilakukan pada bulan Oktober 2020. Peneliti mengumpulkan data melalui google form dan wawancara. Orang tua melakukan berbagai upaya dan strategi untuk mengatasi kejenuhan anak belajar dari rumah. Berdasarkan analisis hasil penelitian ditemukan bahwa orang tua telah melakukan berbagai strategi untuk mengatasi kejenuhan anak selama belajar dari rumah. Sebanyak $60 \%$ orang tua mengajak anak bermain dan rekreasi saat hari libur, 33\% orang tua memberikan dukungan psikologis seperti pemberian motivasi, bujukan, kata-kata penyemangat dan $7 \%$ yang memberikan reward atau hadiah sebagai bentuk apresiasi untuk perilaku positif anak dalam belajar.
\end{abstract}

Kata Kunci: belajar; kejenuhan; anak usia dini, strategi orang tua.

\begin{abstract}
This research aimed at knowing the strategies of parents to overcome the boredom of children learning from home during the covid-19 pandemic. This research was conducted with a descriptive survey research method. The sampling technique used purposive sampling technique, such as parents who have children aged 4 to 6 years. The sample in this research was 105 respondents and was conducted in November 2020. Researchers used data collection techniques through google form and interview. Parents make various efforts and strategies to overcome the boredom of learning from home. From the results of the research findings that respondents have carried out various strategies to overcome children's boredom during school from home, $60 \%$ of parents gave playtime for their children and go on vacation, $33 \%$ of parents gave psychological support such as giving motivation, persuasion, words of encouragement and $7 \%$ gave rewards or gifts as an appreciation for the child's positive behavior in learning.
\end{abstract}

Keywords: learning from home; boredom; earlychildhood; strategy of parents.

Copyright (c) 2019 Ade Agusriani, Mohammad Fauziddin

$\triangle$ Corresponding author :

Email Address : ade.agusriani@uin-alauddin.ac.id ( Makassar, Indonesia )

Received 12 December 2020, Accepted 27 December 2020, Published 5 Januari 2021 


\section{PENDAHULUAN}

Permasalahan Corona Viruses Disease 2019 (Covid-19) yang terjadi hampir di seluruh dunia dan mulai masuk di Indonesia sejak maret 2020 belum terselesaikan hingga sekarang. Pandemi ini memengaruhi berbagai sektor kehidupan diantaranya dalam bidang pendidikan seperti kendala dalam menentukan metode pembelajaran yang tepat, kendala komunikasi orang tua dan guru serta kendala penggunaan teknologi dalam pembelajaran (Agustin et al. 2020). Hal tersebut menyebabkan kebijakan menteri pendidikan dan kebudayaan RI No.3 Tahun 2020 dan Surat Edaran No 4 tahun 2020 masih diberlakukan hingga sekarang. kebijakan tersebut dikenal sebagai kebijakan belajar jarak jauh dalam jaringan (daring) atau online learning. Pembelajaran ini dilakukan tidak secara tatap muka di kelas melainkan dengan menggunakan perangkat elektronik seperti gadget, laptop atau smartphone. Hal tersebut melatarbelakangi masyarakat mengenal istilah belajar dari rumah atau "BDR" yaitu proses pembelajaran yang awalnya berlangsung di sekolah menjadi belajar di rumah yang berakibat signifikan terhadap proses pembelajaran.

PAUD merupakan salah satu jenjang pendidikan yang merasakan dampak penerapan kebijakan belajar di rumah. Proses belajar anak usia dini yang idealnya melalui bermain sambil belajar mengalami perubahan cukup signifikan. Kegiatan belajar anak yang selama ini berlangsung di sekolah beralih ke proses pendidikan di rumah. Pada hakikatnya anak usia dini merupakan masa keemasan. Pada rentang usia ini, anak berada pada proses pertumbuhan dan perkembangan yang pesat. Hal ini ditandai dengan kemampuan anak mengolah informasi ke long term memori secara tajam, keingintahuan yang besar, kemampuan untuk mengeksplor hal baru di lingkungan sekitar. Oleh karenanya, penting untuk memberikan stimulasi atau rangsangan pendidikan yang mampu mengoptimalkan tumbuh dan berkembangnya kemampuan anak sebagai bekal untuk melanjutkan pada jenjang pendidikan selanjutnya. Anak usia dini belajar dengan cara mengamati kemudian mencontoh, melakukan eksperimen berulang kali sehingga anak dapat menemukan pembelajaran (discovery learning) dalam kegiatan bermain.

Pendidikan anak usia dini di Indonesia tidak bisa dilepaskan dari pengaruh Ki Hajar Dewantara sebagai salah satu pelopor pendidikan di Indonesia yang memberikan perhatian lebih dalam dunia pendidikan terutama anak. Ki Hajar Dewantara memandang anak sebagai fitur sentral dalam pendidikan dengan memberikan kebebasan sepenuhnya untuk berkembang. Konsep yang terkenal adalah yang berarti guru membimbing dari belakang dan mengingatkan anak terhadap suatu tindakan yang berbahaya (tut wuri handayani) sambil terus memberi motivasi (ing madya mangun karsa) dan selalu menjadi contoh dalam perilaku dan ucapannya (ing ngarsa sung tuladha) (Soegeng Santoso 2011).

Selama Pandemi ini, tugas mendidik anak yang awalnya dilakukan oleh guru di sekolah, sehingga mengalami pengurangan peran guru dengan hanya menjadi perencana kegiatan dan penilai hasil pembelajaran, sementara untuk proses pelaksana pembelajaran diimplementasikan oleh orang tua di rumah melalui WhatsApps, sebuah aplikasi yang populer digunakan oleh orang tua anak. Persiapan yang dilakukan guru untuk proses pembelajaran dimulai dari rencana pembelajaran, mengkomunikasikan dengan orang tua, dan fasilitas pendukung lainnya (Ayuni et al. 2021). Sedangkan orang tua mendampingi sekaligus membimbing anak belajar di rumah kemudian hasil belajar anak dilaporkan ke guru untuk dinilai dan dievaluasi (Hewi dan Asnawati 2020). Adapun pelaksanaan pembelajaran selama pandemi ini dilakukan dengan beragam aktivitas diantaranya penugasan dari pihak sekolah, kunjungan ke rumah anak (home visit) dan laporan kegiatan harian anak. Berdasarkan penelitian yang dilakukan (Nahdi et al. 2020) diperoleh bahwa implementasi pembelajaran selama covid-19 ini didominasi oleh penugasan dan laporan kegiatan harian, terdapat juga beberapa sekolah menerapkan kolaborasi ketiga aktivitas tersebut. Sedangkan dari segi pengaruh tingkat penghasilan orang tua dengan kegiatan orang tua selama proses pembelajaran daring, tidak berpengaruh signifikan (Adhe et al. 2020). 
Berbagai aktivitas anak yang awalnya di sekolah dan harus dilakukan di rumah pada pengimplementasiannya ditemui berbagai kendala seperti kesulitan belajar dari rumah, menurunnya minat belajar anak, tugas yang terlalu banyak yang memicu kebosanan. Adapun kendala yang dialami orang tua ialah ketidakmampuan dalam memahami materi pelajaran anak, kurang tersedianya waktu untuk mendampingi anak karena disisi lain orang tua juga harus bekerja, kurang sabar dalam mengajari anak, serta kendala dalam penggunaan perangkat dan layanan internet yang masih terbatas (Sulistyawati 2020). Layanan internet yang bermasalah akan secara langung memengaruhi proses komunikasi anak, orang tua dan guru di sekolah. Padahal komunikasi yang efektif antara guru dan anak akan mendorong motivasi anak untuk mengikuti semua proses (Nisa dan Sujarwo 2020). Berbagai masalah dalam proses belajar akan menyebabkan kejenuhan belajar yang akan sangat berdampak bagi peserta didik untuk kelangsungan pendidikannya.

Kejenuhan dalam belajar dapat menyebabkan seseorang cepat marah, mudah terluka dan mudah frustasi (Hidayat 2016). Pemberian tugas yang terlalu banyak dan suasana belajar yang monoton cenderung mendorong sikap sinis dan apatis terhadap pelajaran dengan diberikan, kurang percaya diri dan rendahnya proses memahami pelajaran yang telah diterima (Arirahmanto dan Sutam 2016).

Pengimplementasian belajar selama pandemi di jenjang pendidikan PAUD menjadi dasar dalam penelitian ini. Dalam beberapa hasil penelitian terdahulu tentang penerapan strategi online learning menunjukkan berbagai hasil dan dampak positif. Misal dalam penelitian yang dilakukan Fadlilah (2020) yang mengungkapkan salah satu bentuk strategi guru untuk memotivasi siswa belajar di rumah yaitu dengan mempublikasikan karya siswa. Kemudian dalam penelitian Damayamti \& Masitoh (2020) menunjukkan pentingnya dukungan sosial, kontrol diri, sikap tawakal dan qanaah dalam menghadapi kejenuhan belajar siswa selama pandemi. Selanjutnya Lisman et al., (2020) mengungkapkan bahwa suasana belajar kondusif, hiburan, penggunaan metode dan gaya belajar bervariasi efektif dalam pengelolaan kelas untuk mengatasi kejenuhan belajar siswa.

Beberapa strategi yang telah dipaparkan tersebut menunjukkan hal yang positif dalam keberlangsungan pembelajaran di masa pandemi Covid-19. Oleh karena itu, keberhasilan proses pembelajaran bukan hanya tugas sekolah, guru dan siswa, akan tetapi orang tua memiliki kewajiban untuk mendukung anak memeroleh hasil belajar yang optimal. Dengan perbedaan situasi seperti ini, penting untuk mengkaji strategi atau upaya yang dapat dilakukan oleh orang tua sebagai pihak pelaksana pembelajaran selama anak belajar di rumah untuk mengatasi kejenuhan anak belajar. Oleh karena itu penelitian ini penting untuk dilakukan agar diperoleh hal-hal baru dan hasilnya dapat dimanfaatkan untuk penyempurnaan pelaksanaan pembelajaran selama di rumah. Hasil penelitian ini dapat dimanfaatkan oleh orang tua, guru dan kepala sekolah.

\section{METODOLOGI}

Metode yang digunakan dalam penelitian ini adalah metode survei, yaitu pengambilan data melalui serangkaian pertanyaan yang disusun secara sistematis untuk diisi oleh responden (Yoyo Sudaryo, Sofiati, dan Medidjati 2019). Adapun teknik pengambilan sampel dalam penelitian ini menggunakan teknik purposive sampling, yakni pemilihan sampel dengan pertimbangan yaitu orang tua yang memiliki anak yang berusia 4 hingga 6 tahun yang berdomisili di kota Makassar. Dengan pertimbangan bahwa anak usai 4 tahun sudah mulai terlibat dalam aktivitas belajar di sekolah.

Teknik pengumpulan data dengan menggunakan angket dan wawancara. Penelitian dilakukan menggunakan instrumen berupa angket yang sudah melalui validasi dan uji coba instrumen yang telah layak digunakan. Penyebaran angket dibuat dengan menggunakan google form, yang disebarkan secara online melalui media sosial seperti whatsapp group pada bulan Oktober. Dalam waktu seminggu penyebaran angket diperoleh 105 orang responden. Angket terdiri dari 8 pertanyaan yang berkaitan dengan hal-hal yang dirasakan selama 
mendampingi anak belajar di rumah, kendala-kendala yang dihadapi serta strategi yang diterapkan orang tua untuk mengatasi munculnya rasa jenuh belajar dari rumah. Langkah Selanjutnya dilakukan wawancara mendalam untuk memeroleh informasi tambahan terkait hasil analisis angket. Setelah data terkumpul kemudian dilakukan analisis data dengan teknik presentase. Teknik presentase digunakan untuk mengetahui perolehan presentase yang menunjukkan pada kategori tertentu terkait kendala-kendala dan strategi orang tua dalam mengatasi kejenuhan anak belajar dari rumah. Kemudian dilakukan penarikan kesimpulan sebagai jawaban atas rumusan masalah yang telah ditentukan. Lebih jelasnya alur desain penelitian ini dapat dilihat melalui gambar 1.

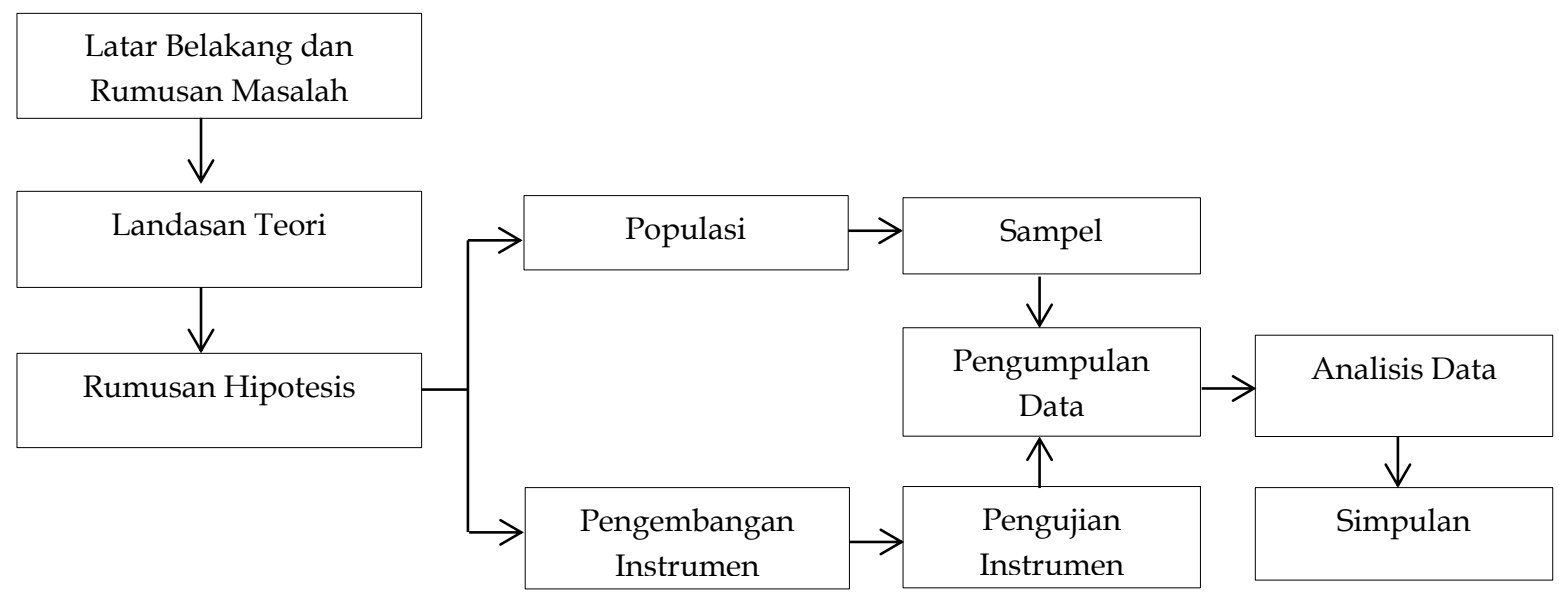

Gambar 1. Desain Penelitian

\section{HASIL DAN PEMBAHASAN}

\section{Kendala-kendala selama belajar dari rumah}

Berdasarkan hasil penelitian, diperoleh berbagai kendala yang dihadapi selama aktivitas BDR baik yang disebabkan oleh gangguan fasilitas internet, perilaku anak selama proses belajar dan kendala orang tua dalam mendampingi anak belajar. Presentase data dapat dilihat pada tabel 1.

Tabel 1. Kendala-kendala Belajar Dari Rumah

\begin{tabular}{ll}
\hline Kendala-kendala BDR & Presentase \\
\hline Perilaku anak & $59 \%$ \\
Dukungan orang tua & $23 \%$ \\
Fasilitas internet & $18 \%$ \\
\hline
\end{tabular}

Hasil penelitian menunjukkan bahwa aktivitas belajar dari rumah yang telah berlangsung lebih dari tujuh bulan menyebabkan sebagian besar anak mengalami berbagai masalah dalam proses belajar. Permasalahan dalam belajar online diantaranya anak tidak berminat mengikuti pembelajaran, malas mengerjakan tugas, kesulitan konsentrasi serta tidak mau mendengarkan nasehat orang tua. Beberapa anak menganggap pembelajaran online tidak menarik, membosankan dan bertambahnya rasa frustasi dan kebingungan, perilaku anak yang tidak disiplin saat jadwal belajar. Berdasarkan wawancara dengan orang tua, mereka merasa kesulitan dalam menghadapi perilaku anak yang tidak patuh saat belajar. Sehingga orang tua perlu menasehati dan membujuk anak agar mau mengerjakan tugas yang diberikan oleh guru.

Adapun kendala yang dihadapi oleh orang tua selama BDR juga turut memengaruhi keefektifan proses belajar anak. Hasil wawancara menunjukkan orang tua merasa kurang optimal dalam mendampingi anak selama BDR karena kurang paham materi pelajaran dan 
kelelahan dalam menjalankan multi peran. Multi peran orangtua yang dimaksud dalam penelitian ini disebabkan oleh beragam latar pekerjaan dan jumlah anak orangtua dalam satu keluarga. Responden dalam penelitian ini terdiri dari 70\% orangtua yang bekerja di rumah, $21 \%$ karyawan swasta dan 9\% ASN. Meskipun penelitian ini didominasi oleh orangtua yang bekerja di rumah akan tetapi $80 \%$ lebih orang tua memiliki jumlah anak lebih dari satu dengan usia anak masih di bawah 6 tahun. Sehingga hal tersebut berpengaruh pada manajemen waktu orang tua dalam mendampingi anak belajar, mengasuh anak lainnya dan mengelola pekerjaan rumah. Dalam hal pendampingan belajar anak, hasil penelitian menunjukkan ibu bertanggung jawab lebih besar dibandingkan ayah karena sebagian besar waktu ibu berada di rumah berbeda dengan ayah yang harus bekerja dan berada di luar rumah. Berbagai peran tersebut menyebabkan orangtua dalam hal ini ibu sebagai pihak yang paling rentan mengalami kelelahan dalam menjalankan perannya dan berdampak pada pola asuh terhadap anak.

Kendala lainnya yang ditemukan dalam proses belajar dari rumah adalah gangguan layanan dan perangkat internet. Internet merupakan faktor penting kelancaran dalam pembelajaran online sehingga hal ini harus dipersiapkan sebelum kegiatan belajar berlangsung. Adapun kendala internet yang ditemukan dalam penelitian ini terkait kendala jaringan internet yang kurang lancar, mahalnya biaya pembelian kuota internet serta keterbatasan kesediaan perangkat seperti smartphone menjadi permasalahan yang tidak dapat dihindari selama BDR. Layanan jaringan internet yang masih belum merata di wilayah Indonesia termasuk di kota Makassar. Kwalitas suara dan kejernihan tampilan video dalam pembelajaran masih kurang sehingga berpengaruh dalam proses penerimaan informasi dalam belajar, selanjutnya penggunaan kuota internet yang cukup banyak dalam sehingga akan menambah jumlah pengeluaran orang tua.

\section{Strategi Mengatasi Kejenuhan Belajar dari Rumah}

Berdasarkan hasil penelitian, ditemukan berbagai upaya yang dilakukan oleh orang tua untuk mengatasi kejenuhan anak saat aktivitas belajar dari rumah. Hasil pengolahan data dapat dilihat pada tabel 2 .

Tabel 2. Strategi Mengatasi Kejenuhan Belajar Dari Rumah

\begin{tabular}{ll}
\hline Strategi mengatasi kejenuhan belajar dari rumah & Presentase \\
\hline Bermain dan Rekreasi & $60 \%$ \\
Kata-kata motivasi & $33 \%$ \\
Hadiah & $7 \%$ \\
\hline
\end{tabular}

Temuan dalam penelitian ini menunjukkan bahwa orang tua telah memiliki kesadaran lebih untuk mengatasi kejenuhan anak selama belajar di rumah. Hal tersebut terlihat dari berbagai upaya yang dilakukan untuk meningkatkan motivasi anak dalam belajar. Upaya yang dilakukan orang tua untuk mengatasi rasa bosan anak adalah mengajak anak untuk bermain di luar rumah serta mengajak anak rekreasi pada hari libur. Berdasarkan hasil wawancara dengan orang tua, setelah anak melakukan aktivitas bermain anak akan kembali bersemangat dan siap untuk belajar kembali. Bermain dapat dilakukan di dalam dan di luar rumah dengan beragam cara. Kegiatan bermain di dalam rumah dapat dilakukan bersama anak dan orang tua sehingga akan membangun kedekatan fisik dan emosional diantara keduanya. Beberapa orang tua berinisiatif untuk membolehkan anak bermain di luar rumah dengan mengajak anak rekreasi atau mengunjungi tempat-tempat wisata seperti di pantai atau taman. Hal ini dianggap efektif oleh orangtua untuk menghilangkan kejenuhan selama berada di rumah karena dapat merilekskan pikiran.

Adapun upaya lain yang dilakukan orang tua adalah dengan memberikan dukungan psikologis melalui kata-kata motivasi, semangat, bujukan serta pemberian reward berupa makanan kesukaan anak. Motivasi belajar dapat distimulus dengan sesuatu dari dalam 
maupun dari luar diri anak. Makanan merupakan sesuatu dari luar diri anak yang dapat mendorong lahirnya motivasi belajar sehingga hal tersebut merupakan langkah yang tepat untuk dilakukan oleh orang tua. Berdasarkan temuan wawancara dengan orang tua, memberikan makanan kesukaan pada anak merupakah cara efektif agar anak merasa senang dan ingin melanjutkan kegiatan belajar di rumah.

Selain upaya tersebut, strategi lainnya yang dilakukan adalah membantu anak mengerjakan tugas yang belum dipahami. Orang tua berkoordinasi dengan guru untuk membahas tugas yang kurang dipahami oleh orang tua sekaligus untuk melaporkan perkembangan proses belajar anak. Untuk mendapatkan hasil yang lebih mendalam, peneliti melakukan wawancara terhadap beberapa subjek penelitian. Peneliti menemukan bahwa salah satu cara yang efektif dilakukan orang tua untuk mencegah anak mengalami kejenuhan dalam belajar ialah mempersiapkan kebutuhan anak sebelum proses belajar dimulai. Persiapan sebelum belajar yang dilakukan orang tua adalah memandikan anak terlebih dahulu agar anak lebih siap secara fisik dan mental untuk menerima pelajaran, menyiapkan ruang khusus untuk belajar baik di dalam rumah atau di luar rumah seperti di taman. Hal tersebut penting dilakukan untuk memisahkan ruangan yang tenang dan bising dalam pengelolaan ruang belajar.

\section{Pembahasan}

\section{Kendala-kendala selama belajar di rumah.}

Belajar merupakan suatu proses perubahan dalam diri manusia yang nampak dalam bentuk peningkatan perilaku baik secara kuantitas dan kualitas seperti kecakapan, pengetahuan, kebiasaan, daya pikir dan berbagai kemampuan lainnya (Thursan Hakim 2005). Pembelajaran idealnya dirancang dan diselenggarakan secara interaktif dan menyenangkan untuk mendorong kreativitas dan kemandirian anak sesuai tahapan perkembangannya. Hal tersebut akan dapat dilakukan jika proses pembelajaran dilaksanakan dengan adanya perencanaan dari guru dan situasi mendukung disekitarnya. Proses pembelajaran yang berlangsung tanpa perencanaan yang matang dan pelaksanaan yang kondusif akan menyebabkan munculnya berbagai kendala, termasuk dalam proses belajar di rumah selama pandemi covid-19.

Berdasarkan tabel 1 dapat dilihat bahwa perilaku anak merupakan salah satu kendala belajar di rumah yang dihadapi oleh anak selama aktivitas belajar dari rumah. Anak mengalami rasa bosan mengikuti pembelajaran, malas mengerjakan tugas, kesulitan konsentrasi serta tidak mau mendengarkan nasehat orang tua. (Sari et al., 2020) yang mengemukakan bahwa munculnya rasa bosan berada di rumah dalam jangka waktu yang lama adalah suatu hal yang normal karena, pada fitrahnya manusia adalah makhluk sosial yang membutuhkan interaksi dengan lingkungan sekitar. Putri et al., (2020) mengungkapkan hasil penelitiannya bahwa salah satu kendala proses belajar di masa pandemi adalah siswa kurang bersosialisasi dan komunikasi dengan teman sebaya, kurang disiplin dalam belajar terutama anak di bawah kelas 4 sekolah dasar.

Berbagai gejala yang dialami dalam belajar online menyebabkan ketidakseimbangan komponen psikologis yang dibutuhkan dalam proses pembelajaran yang disebabkan kejenuhan belajar (Dhawan 2020). Perilaku yang sering ditunjukkan oleh orang yang mengalami kejenuhan belajar diantaranya mudah marah, sensitif dan rentan frustasi yang berakibat pada penurunan konsentrasi dan kemampuan memahami intisari materi pelajaran. Kejenuhan belajar dapat mengakibatkan menurunnya konsentrasi dan daya serap dari materi yang diberikan (Hidayat 2016; Siti Rohimah 2020). Rahman (2007) menambahkan bahwa kejenuhan dalam belajar akan memberikan dampak negatif terhadap hasil belajar, sehingga proses pembelajaran tidak akan optimal.

Kendala lain yang ditemui dalam proses belajar dari rumah adalah ketidakmampuan orang tua mendampingi anak secara maksimal belajar dari rumah disebabkan kelelahan yang dialami orang tua. Kelelahan tersebut dipengaruhi oleh multi peran orang tua sebagai 
pendidik, pembimbing, pengawas dan pengelola rumah agar rumah senantiasa tetap nyaman dan mendukung aktivitas anggota keluarganya selama belajar dari rumah (Kurniati, Nur Alfaeni, dan Andriani 2020). Di masa pandemi ini, kelelahan rentan dialami oleh orang tua yang dapat berakibat pada perubahan signifikan, karena orang tua yang kelelahan cenderung terlibat dalam penelataran anak (Griffith 2020). Berbagai kendala yang terjadi selama proses belajar menyebabkan anak dan orang tua menginginkan kembali belajar di sekolah. Hal tersebut sejalan dengan penelitian yang dilakukan oleh Sari et al., (2020) yang mengungkap bahwa $61 \%$ anak menjadi rewel belajar di rumah karena rindu suasana belajar di sekolah bersama teman dan gurunya. Di sisi lain, anak merasa bosan seharian di rumah, ibu juga merasa kurang sabar dan kelelahan karena selain harus mengerjakan urusan rumah tangga juga harus mendampingi anak belajar.

Kebersihan dan kenyamanan lingkungan rumah dapat menumbuhkan bakat dan kreativitas anak di masa pandemi (Huda dan Munastiwi 2020). Ruangan yang tenang akan membantu seseorang dalam berkonsentrasi dan meminimalisir faktor-faktor yang dapat mengalihkan perhatian anak saat belajar (Rita Maryana \& Rachmawati, 2010) Hal tersebut sesuai dengan hasil penelitian yang dilakukan Kurniawan (2019) bahwa pentingnya menata ruang belajar senyaman mungkin dengan selalu menjaga kebersihan ruangan, penataan warna cat ruangan yang terang dan memajang gambar yang menarik untuk menjaga semangat belajar anak. Penataan ruang belajar akan berdampak pada mutu pembelajaran. Mengatur jadwal bermain anak juga merupakan startegi yang efektif untuk mengatasi kejenuhan belajar. Pada anak usia dini, pembelajaran yang menarik dan menyenangkan memegang peranan yang penting bagi perkembangan di usia selanjutnya sehingga anak perlu untuk mendapatkan stimulasi yang tepat. Stimulasi dapat dilakukan melalui bermain, hal ini penting dan tidak bisa dipisahkan dari dunia anak karena melalui bermain anak dapat mengembangkan aspek-aspek perkembangan dalam dirinya. Berbagai kendala yang dihadapi oleh orang tua harus bisa segera diatasi karena orang tua memegang peranan penting dalam penyelenggaraan pendidikan yang berkwalitas (Putri et al. 2020).

Kendala belajar dari rumah yang ketiga dalam penelitian ini adalah minimnya fasilitas yang mendukung dalam pembelajaran online. Sebanyak 18\% menunjukkan kendala BDR seperti jaringan internet yang kurang lancar, pembiayaan untuk membeli kuota serta ketersediaan perangkat terutama yang dialami oleh orang tua yang memiliki anak sekolah lebih dari satu. Hal tersebut sejalan dengan hasil penelitian Dhawan (2020) yang menyatakan bahwa pembelajaran online yang dilakukan di masa pandemi merupakan solusi yang tepat agar proses pembelajaran dapat terus berlangsung karena bersifat fleksibel dalam hal waktu dan lokasi. Namun demikian, pembelajaran online masih mengalami beberapa kendala seperti gangguan dalam instalasi, gangguan login, audio, video dan sebagainya. Hasil penelitian Sadikin \& Hamidah (2020) yang dilakukan pada jenjang perguruan tinggi juga mengungkapkan bahwa ketersediaan layanan internet yang masih kurang optimal di berbagai wilayah di Indonesia dan pembiayaan internet yang mahal masih menjadi tantangan tersendiri dalam pembelajaran daring yang perlu menjadi perhatian dari pemerintah untuk bisa segera diatasi.

\section{Strategi Mengatasi Kejenuhan Belajar dari Rumah \\ Interaksi antara bermain, rekreasi dan Optimalisasi Perkembangan}

Aktivitas bermain merupakan sesuatu yang dapat dilakukan dengan atau tanpa menggunakan objek. Bermain bertujuan untuk mengoptimalkan stimulasi perkembangan anak. Dalam bermain, anak akan terstimulasi untuk menunjukkan kemampuan tertentu yang berhubungan dengan pertumbuhan dan perkembangan kognitif serta memberi kemungkinan bertambahnya kemampuan pada aspek perkembangan lainnya seperti sosial. Belsky menyatakan bahwa terdapat berbagai macam kemampuan yang ada dalam aktivitas bermain diantaranya kemampuan berbicara, manipulasi secara sederhana, menggunakan suatu alat berdasarkan kegunaannya, kemampuan dalam mengombinasikan suatu objek secara 
berpasangan serta penggunaan suatu objek sesuai dengan fungsi yang sebenarnya (Suminar 2019). Dalam bermain, anak juga akan mampu melakukan suatu secara berpura-pura, berkhayal dalam cerita yang dirangkainya sendiri serta anak mampu mengganti alat permainan dengan objek yang lain.

Berdasarkan hasil penelitian, mengajak anak bermain dan berinteraksi dengan dunia luar adalah upaya yang yang sering dilakukan orang tua dan dianggap efektif untuk mengatasi rasa bosan belajar dari rumah. Melalui bermain, anak akan merasakan kebebasan dan kebahagiaan. Hal tersebut sesuai dengan yang dikemukakan Hurlock (2002) bahwa bermain merupakan aktivitas yang dilakukan untuk memeroleh kesenangan tanpa memerdulikan hasil akhirnya. Bermain dilakukan secara suka rela dan tanpa paksaan ataupun tekanan dari luar. Ismail (2012) mengungkapkan bahwa bermain memiliki efek relaksasi dan penyegaran kembali kondisi fisik dan mental yang penuh dengan tekanan. Sejalan dengan prinsip pembelajaran pada anak usia dini yang dilakukan melalui aktivitas bermain, metode ini merupakan metode yang paling digemari oleh siswa. Anak dapat belajar secara maksimal apabila orang tua memahami tipe anak, memberikan games education, mendampingi anak belajar dan bersikap tegas kepada anak untuk memaksimalkan cara belajarnya (Zakiah Daradjat 2016).

Bermain dan permainan adalah sesuatu yang memiliki perbedaan. Permainan atau game adalah aktivitas bermain yang terdapat serangkaian aturan bermain dan memuat unsur kompetisi. Permainan dapat berlangsung saat anak telah memahami aturan yang berlaku dalam bermain. Berbeda dengan bermain yang terkadang ada atau tanpa aturan, bermain memberikan rasa senang sedangkan permainan akan memberikan rasa senang, suasana kompetisi dan menegangkan (Suminar 2019)

Lima karakteristik suatu kegiatan dikelompokkan sebagai bermain, yaitu (1) bermain adalah kegiatan yang didorong dari dalam diri, bermula dan berakhir dengan sendirinya, dilakukan dan diakhiri dengan kepuasan. (2) tidak ada paksaan bagi pemain dalam memilih permainan yang diinginkan (3) kegiatan bermain untuk berlangsung menyenangkan dan orang dewasa bertugas untuk mengamati permainan anak (4) kegiatan bermain berlangsung nonliteral atau tidak nyata, sebagai bentuk realitas yang diinginkan oleh pemain (5) bermain adalah aktifitas yang melibatkan fisik, psikologis ataupun keduanya tidak sekedar pasif (Agusriani 2015).

Dalam penelitian ini, aktivitas bermain yang dilakukan oleh anak dapat berlangsung di rumah atau di luar rumah seperti mengunjungi tempat rekreasi. Saadah et al., (2020) menyatakan bahwa rekreasi bertujuan untuk penyegaran jasmani dan rohani. Pada umumnya, rekreasi dilakukan pada akhir pekan. Rekreasi merupakan kegiatan yang memberikan efek kebugaran pada fisik, mental dan sosial serta memberi rasa nyaman pada tubuh. Dalam penelitian ini, peneliti menggabungkan aktivitas rekreasi dan bermain karena memiliki tujuan mencari kesenangan, mengisi waktu luang dan berolahraga serta memberikan pengaruh terhadap optimalisasi perkembangan anak. Oleh karena itu, rekreasi adalah suatu kegiatan yang penting dilakukan oleh anak untuk meninggalkan sejenak rutinitas sehari-hari, melepas lelah sehingga anak akan lebih bersemangat untuk melanjutkan pembelajarannya di kemudian hari.

\section{Pentingnya Motivasi dalam Pembelajaran}

Dukungan psikologis seperti motivasi, kata-kata penyemangat, membujuk anak untuk menyelesaikan tugas serta mengajak anak bersenda gurau merupakan upaya yang dapat dilakukan untuk mengatasi kejenuhan anak belajar. Santrock (Sitorus 2020) mengemukakan bahwa motivasi merupakan suatu proses untuk memberi energi yang terarah dan mempertahankan perilaku. Siagian juga menyatakan bahwa motivasi merupakan kemampuan untuk menggerakkan seseorang untuk berkontribusi mencapai tujuan yang diharapkan. Adapun ahli lain mengatakan bahwa motivasi belajar adalah suatu perubahan tenaga di dalam diri seseorang yang ditandai dengan timbulnya perasaan dan reaksi untuk 
mencapai tujuan. Oleh karena itu motivasi belajar merupakan dorongan untuk belajar secara sungguh-sungguh dan penuh konsentrasi sehingga dapat mencapai tujuan yang diinginkan.

Motivasi siswa dapat terlihat dalam keterlibatannya secara kognitif, emosional dalam berbagai aktivitas di sekolah. Motivasi memiliki beberapa pengaruh terhadap proses pembelajaran perilaku yakni motivasi akan mengarahkan seorang siswa pada tujuan tertentu, mendorong siswa dalam bersungguh-sungguh mengerjakan tugas atau malas-malasan, serta memengaruhi proses-proses kognitif. Motivasi dapat dibentuk oleh sesuatu yang berada di luar individu yang dikenal sebagai motivasi ekstrinsik, dan motivasi juga dapat dipengaruhi oleh faktor-faktor di dalam diri yang dikenal sebagai motivasi intrinsik. Saad (2007) menyatakan bahwa pemberian motivasi adalah suatu hal yang penting dilakukan untuk memunculkan perilaku yang diharapkan. Dalam hal ini, perilaku yang diharapkan adalah anak mau belajar dan tidak merasa bosan belajar dari rumah. Oleh karena itu, pemberian motivasi, bujukan akan membuat anak merasa dihargai. Zeleeva et al., (2016) menyatakan bahwa pentingnya dukungan psikologis dalam proses pembelajaran akan mendorong kemampuan siswa untuk memasuki sistem pembelajaran baru dan meningkatkan perkembangan psikologis siswa.

Pentingnya memotivasi anak untuk semangat belajar disertai dengan sikap disiplin. Salah satu strategi yang dilakukan oleh guru untuk meningkatkan motivasi belajar siswa ialah memberikan permainan atau games di sela-sela waktu belajar. Hal tersebut juga ditunjang dengan teknik pembelajaran dengan ice breaking serta pemberian penghargaan kepada siswa yang berhasil mengerjakan tugasnya (Kurniawan 2019). Sebagaimana dalam perspektif behavioral yang menyatakan bahwa pemberian motivasi menitik beratkan pada reward dan punishment eksternal.

Berdasarkan hasil penelitian dilaporkan bahwa salah satu reward yang dapat diberikan oleh guru adalah dengan menampilkan hasil karya anak di media sosial sehingga dapat dilihat oleh publik dan hal tersebut akan memunculkan kebahagiaan tersendiri bagi anak. Berdasarkan komponen tersebut, maka dapat disimpulkan bahwa motivasi belajar memiliki beberapa jenis dan juga mengangandung komponen, antara lain menggerakkan, mengarahkan, dan menopang atau menjaga tingkah laku. Pada dasarnya motivasi itu dapat muncul dari diri sendiri maupun dari orang lain, sehingga para siswa mampu meningkatkan motivasi belajarnya bisa karena dirinya sendiri maupun dari orang lain (Sari et al. 2020).

Presentase terkecil dalam upaya untuk mengatasi rasa bosan belajar dari rumah adalah pemberian hadiah atau reward. Sebanyak $7 \%$ orang tua memberi hadiah berupa makanan kesukaan anak. Reward merupakan bentuk apresiasi yang diberikan guru atau orang tua kepada anak yang mengikuti proses belajar dan mengerjakan tugas hingga tuntas. Reward dapat diberikan melalui verbal dan non verbal, memberikan makanan yang disukai oleh anak menjadi pilihan orang tua untuk menjaga semangat belajar anak di rumah (Dhawan 2020). Hal tersebut penting untuk dilakukan karena perilaku baik memerlukan dukungan dan apresiasi, sejalan dengan teori belajar yang dikemukakan oleh Skinner bahwa reward merupakan faktor penting dalam proses belajar karena akan memotivasi dan membuat siswa menjadi lebih giat belajar (Saad 2007).

Reward dan punishment merupakan bentuk penguatan atas sikap dan perilaku anak. Reward adalah penguatan dalam bentuk hadiah, sedangkan punishment adalah hukuman ditujukan atas perilaku anak. Reward dan punishment merupakan sarana yang mendorong seseorang untuk melakukan perubahan perilaku agar tercapai hasil yang diharapkan. Terbentuk persepsi ditengah masyarakat bahwa pemberian reward dan punishment akan selalu bisa memotivasi anak padahal, terkadang ada anak yang tidak termotivasi meskipun telah diberikan reward dan punishment. Hal tersebut dipengaruhi oleh kekebalan terhadap hadiah atau hukuman. Oleh karena itu, orang tua harus memiliki tujuan yang jelas dalam pemberian reward. Hal ini akan mendorong anak untuk lebih bersemangat, berbeda jika orang tua tidak memiliki dasar kuat memberikan reward maka tidak akan memberikan efek apapun terhadap anak (Murdoko 2017) 
Dalam pemberian reward dan punishment, orang tua juga perlu untuk menegaskan kepada anak bahwa punishment dan reward ditujukan untuk sikap dan perilaku tertentu anak, bukan pada pribadi anak oleh karena itu diperlukan komunikasi terbuka antara keduanya agar anak bisa memahami dengan baik. Rosyid \& Aminal Rosid Abdullah (2018) mengemukakan beberapa alasan mengapa pemberian metode reward efektif dalam pendidikan yaitu peserta didik akan terbantu dalam meningkatkan kemampuan dan proses kognitif, informasi yang didapatkan melalui metode ini bersifat pribadi, menimbulkan rasa senang pada anak didik dan memungkinkan anak didik berkembang cepat sesuai dengan kecepatannya sendiri.

\section{SIMPULAN}

Pada umumnya anak mengalami kejenuhan belajar di rumah yang ditunjukkan dengan rendahnya antusiasme mengikuti pembelajaran daring dan kesulitan belajar bersama orang tua di rumah. Oleh karena itu, orang tua perlu melakukan berbagai cara untuk mengatasi kebosanan anak. Adapun strategi yang efektif perlu dilakukan orang tua adalah menyiapkan ruang belajar di rumah atau di luar rumah sehingga anak terkondisikan siap untuk menerima pelajaran. Selanjutnya, mengajak anak bermain di luar rumah, pemberian dukungan psikologis, hadiah dan mengajak anak refreshing atau rekreasi pada hari libur. Hal tersebut mampu memberikan efek relaksasi terhadap rasa lelah yang dialami orang tua dan anak.

\section{UCAPAN TERIMA KASIH}

Terima kasih Peneliti ucapakan kepada Bapak Rektor UIN Alauddin Makassar yang telah memotivasi dalam penyelesaian tulisan dan para orang tua yang telah memberikan tanggapannya untuk tulisan ini.

\section{DAFTAR PUSTAKA}

Adhe, Kartika Rinakit, Rohmatul Maulidiya, Muchamad Arif Al Ardha, Wulan Patria Saroinsong, dan Sri Widayati. 2020. "Learning During the Covid-19 Pandemic: Correlation Between Income Levels And Parental Roles." Jurnal Obsesi: Jurnal Pendidikan Anak Usia Dini 5(1):293. doi: 10.31004/obsesi.v5i1.554.

Agusriani, Ade. 2015. "Peningkatan Motorik Kasar Dan Kepercayaan Diri Melalui Bermain Gerak." Jurnal Pendidikan Usia Dini 9(1):33-50. doi: 10.21009/JPUD.091.03.

Agustin, Mubiar, Ryan Dwi Puspita, Dinar Nurinten, dan Heni Nafiqoh. 2020. "Tipikal Kendala Guru PAUD dalam Mengajar pada Masa Pandemi Covid 19 dan Implikasinya." Jurnal Obsesi: Jurnal Pendidikan Anak Usia Dini 5(1):334. doi: 10.31004/obsesi.v5i1.598.

Arirahmanto, dan Bayu Sutam. 2016. "Pengembangan Aplikasi Penurunan Kejenuhan Belajar Berbasis Android Untuk Siswa SMPN 3 Babat." Jurnal Mahasiswa Bimbingan Konseling 6(2).

Ayuni, Despa, Tria Marini, Mohammad Fauziddin, dan Yolanda Pahrul. 2021. "Kesiapan Guru TK Menghadapi Pembelajaran Daring Masa Pandemi Covid-19." Jurnal Obsesi : Jurnal Pendidikan Anak Usia Dini 5(1):414-21. doi: 10.31004/obsesi.v5i1.579.

Damayamti, Della Tri, dan Alviyatun Masitoh. 2020. "Strategi Koping Siswa dalam Menghadapi Stres Akademik di Era Pandemi Covid-19." Academica: Journal Of Multidisciplinary Studies 4(2):185-98.

Dhawan, Shivangi. 2020. "Online Learning: A Panacea in the Time of COVID-19 Crisis." Journal of Educational Technology Systems 49(1):5-22. doi: 10.1177/0047239520934018.

Fadlilah, Azizah Nurul. 2020. "Strategi Menghidupkan Motivasi Belajar Anak Usia Dini Selama Pandemi COVID-19 melalui Publikasi." Jurnal Obsesi : Jurnal Pendidikan Anak Usia Dini 5(1):373. doi: 10.31004/obsesi.v5i1.548. 
DOI: 10.31004/obsesi.v5i2.961

Griffith, Annette K. 2020. "Parental Burnout and Child Maltreatment During the COVID-19 Pandemic." Journal of Family Violence 23:1-7. doi: 10.1007/s10896-020-00172-2.

Hewi, La, dan Linda Asnawati. 2020. "Strategi Pendidik Anak Usia Dini Era Covid-19 dalam Menumbuhkan Kemampuan Berfikir Logis." Jurnal Obsesi : Jurnal Pendidikan Anak Usia Dini 5(1):158. doi: 10.31004/obsesi.v5i1.530.

Hidayat, Muhammad Yusuf. 2016. "Pengaruh Slow Learner Dan Kejenuhan Belajar Terhadap Kesulitan Belajar Fisika Siswa Mts. Madani Alauddin Paopao Kabupaten Gowa." Pengaruh Slow Learner dan Kejenuhan Belajar 5(2):332-41. doi: 10.24252/ip.v5i2.3487.

Huda, Khairul, dan Erni Munastiwi. 2020. "Strategi Orang tua dalam Mengembangkan Bakat Dan Kreativitas Di Era Pandemi Covid-19." Jurnal Pendidikan Glasser 4(2):80-87.

Hurlock, Elizabeth. 2002. Psikologi perkembangan: Suatu pendekatan sepanjang rentang kehidupan. Surabaya: Erlangga.

Ismail, Andang. 2012. Education Games Panduan Praktis Permainan yang Menjadikan Anak Anda Cerdas, Kreatif, dan Saleh. Yogyakarta: Pro U Media.

Kurniati, Euis, Dina Kusumanita Nur Alfaeni, dan Fitri Andriani. 2020. “Analisis Peran Orang Tua dalam Mendampingi Anak di Masa Pandemi Covid-19." Jurnal Obsesi : Jurnal Pendidikan Anak Usia Dini 5(1):241. doi: 10.31004/obsesi.v5i1.541.

Kurniawan, Asep. 2019. "Manajemen Kelas Pendidikan Anak Usia Dini ( Paud ) Dalam Meningkatkan Kedisiplinan Belajar Siswa." AWLADY: Jurnal Pendidikan Anak 5(2):7894. doi: http:// dx.doi.org/10.24235/awlady.v5i2.4442.g2445.

Lisman, Markuna, dan Helmi Wicaksono. 2020. "Strategi Guru dalam Mengatasi Kejenuhan Belajar Siswa di MTs Al-Maarif Banyorang." Jurnal Al-Qiyam 1(1):54-69.

Murdoko, E. Widijo Hari. 2017. Parenting With Leadership, Peran Orangtua dalam Mengoptimalkan dan Memberdayakan Potensi Anak. diedit oleh PT Elex Media Komputindo. Jakarta.

Nahdi, Khirjan, Sandy Ramdhani, Riyana Rizki Yuliatin, dan Yul Alfian Hadi. 2020. "Implementasi Pembelajaran pada Masa Lockdown bagi Lembaga PAUD di Kabupaten Lombok Timur." Jurnal Obsesi : Jurnal Pendidikan Anak Usia Dini 5(1):177. doi: 10.31004/obsesi.v5i1.529.

Nisa, Khairun, dan Sujarwo Sujarwo. 2020. “Efektivitas Komunikasi Guru terhadap Motivasi Belajar Anak Usia Dini." Jurnal Obsesi : Jurnal Pendidikan Anak Usia Dini 5(1):229. doi: 10.31004/obsesi.v5i1.534.

Putri, Dina Kartika, Myrnawati Crie Handayani, dan Zarina Akbar. 2020. “Pengaruh Media Pembelajaran dan Motivasi Diri terhadap Keterlibatan Orang Tua dalam Pendidikan Anak Abstrak." Jurnal Obsesi: Jurnal Pendidikan Anak Usia Dini 4(2):649-57. doi: 10.31004/obsesi.v4i2.418.

Rahman, Ulfiani. 2007. "Mengenal Burnout Pada guru." Lentera Pendidikan 10(2):216-27.

Rosyid, Zaiful, dan Aminal Rosid Abdullah. 2018. Reward \& Punishment dalam Pendidikan. Malang: Literasi Nusantara.

Saad, Musthafa Abu. 2007. 30 Strategi Mendidik Anak: Cerdas Emosional, Spiritual, Intelektual. Jakarta: Maghfirah Pustaka.

Saadah, Nurlailis, Suparji, dan Sulikah. 2020. Saadah, N., Suparji.,E Sulikah. (2020). Stimulasi Perkembangan Oleh Ibu Melalui Bermain dan Rekreasi Pada Anak Usia Dini. Surabaya: Scopindo Media Pustaka.

Sadikin, Ali, dan Afreni Hamidah. 2020. "Pembelajaran Daring di Tengah Wabah Covid-19." Biodik 6(2):109-19. doi: 10.22437/bio.v6i2.9759.

Sari, Diah Andika, Rahmita Nurul Mutmainah, Ika Yulianingsih, Tiara Astari Tarihoran, dan Munifah Bahfen. 2020. "Kesiapan Ibu Bermain Bersama Anak Selama Pandemi Covid19, 'Dirumah Saja.'” Jurnal Obsesi: Jurnal Pendidikan Anak Usia Dini 5(1):475. doi: 10.31004/obsesi.v5i1.584.

Siti Rohimah. 2020. "Kejenuhan belajar dalam perspektif teori konseling rational emotive behavior therapy." Universitas Islam Negri Sultan Syarif Kasim Riau. 
Sitorus, Raja Maruli Tua. 2020. Pengaruh Komunikasi Antarpribadi Pimpinan Terhadap Motivasi Kerja. Surabaya: Scopindo Media Pustaka.

Soegeng Santoso. 2011. Konsep Pendidikan Anak Usia Dini Menurut Pendirinya 1. Jakarta: Anonymous.

Sulistyawati, Theresia Endang. 2020. “Perspektif Aksiologi Terhadap Penurunan Minat Belajar Anak di Masa Pandemi." Aksiologi: Jurnal Pendidikan dan Ilmu Sosial 1(1):33-43. doi: 10.47134/aksiologi.v1i1.16.

Suminar. 2019. Bermain dan Permainan bagi Perkembangan Anak. Surabaya: Airlangga University Press.

Thursan Hakim. 2005. Belajar Secara Efektif. Jakarta: Puspa Swara.

Yoyo Sudaryo, Nunung Ayu Sofiati, dan R. Adam Medidjati. 2019. Metode Penelitian Survei Online dengan Google Forms. Yogyakarta: Andi Offset.

Zakiah Daradjat. 2016. Metodik Khusus Pengajaran Agama Islam. Jakarta: Bumi Aksara.

Zeleeva, Vera P., Svetlana S. Bykova, dan Silvia Varbanova. 2016. "Psychological and pedagogical support for students' adaptation to learning activity in high science school." International Journal of Environmental and Science Education 11(3):151-61. doi: 10.12973/ijese.2016.299a. 